\title{
Disruption of insulin-like growth factor-II imprinting during embryonic development rescues the dwarf phenotype of mice null for pregnancy-associated plasma protein-A
}

\author{
Laurie K Bale and Cheryl A Conover \\ Endocrine Research Unit, Division of Endocrinology, Metabolism and Nutrition, Mayo Clinic College of Medicine, 200 First Street SW, 5-194 Joseph, \\ Rochester, Minnesota 55905, USA \\ (Requests for offprints should be addressed to C A Conover; Email: Conover.Cheryl@mayo.edu)
}

\begin{abstract}
Pregnancy-associated plasma protein-A (PAPP-A), an insulin-like growth factor-binding protein (IGFBP) protease, increases insulin-like growth factor (IGF) activity through cleavage of inhibitory IGFBP-4 and the consequent release of IGF peptide for receptor activation. Mice homozygous for targeted disruption of the PAPP-A gene are born as proportional dwarfs and exhibit retarded bone ossification during fetal development. Phenotype and in vitro data support a model in which decreased IGF-II bioavailability during embryogenesis results in growth retardation and reduction in overall body size. To test the hypothesis that an increase in IGF-II during embryogenesis would overcome the growth deficiencies, PAPPA-null mice were crossed with $\Delta \mathrm{H} 19$ mutant mice, which have increased IGF-II expression and fetal overgrowth due
\end{abstract}

to disruption of IgfII imprinting. $\Delta \mathrm{H} 19$ mutant mice were $126 \%$ and PAPP-A-null mice were $74 \%$ the size of controls at birth. These size differences were evident at embryonic day 16.5. Importantly, double mutants were indistinguishable from controls both in terms of size and skeletal development. Body size programmed during embryo development persisted post-natally. Thus, disruption of IgfII imprinting and consequent elevation in IGF-II during fetal development was associated with rescue of the dwarf phenotype and ossification defects of PAPP-A-null mice. These data provide strong genetic evidence that PAPP-A plays an essential role in determining IGF-II bioavailability for optimal fetal growth and development. Journal of Endocrinology (2005) 186, 325-331

\section{Introduction}

Insulin-like growth factor (IGF)-II is a major determinant of fetal growth. Targeted disruption of the mouse IgfII gene produces proportional dwarfs, which are $60 \%$ of normal birthweight (DeChiara et al. 1990). The onset of the mutational effect leading to this growth deficiency occurs during early embryogenesis due to loss of the growth-promoting function of IGF-II mediated through signaling via type I IGF and insulin receptors (Baker et al. 1993, Louvi et al. 1997, Burns \& Hassan 2001).

IGF action is determined not only by ligand and receptors but also by a family of IGF binding proteins (IGFBP-1 through -6) that, in turn, are regulated by specific proteases (Shimasaki \& Ling 1991, Rechler \& Clemmons 1998, Bunn \& Fowlkes 2003). One of these proteases was identified as pregnancy-associated plasma protein-A (PAPP-A) (Lawrence et al. 1999). PAPP-A has been shown to cleave inhibitory IGFBP-4 and consequently increase the IGF available for receptor activation in various cell systems in vitro (Conover et al. 1995, Byun et al. 2001, Ortiz et al. 2003). In vivo, intact IGFBP-4 is postulated to form a local reservoir of IGFs that can be made available at critical times through regulated expression of PAPP-A and its associated proteolytic activity (Pintar et al. 1998). Recently, we generated PAPP-A-null mice which, similar to IGF-II-null mice, were born as proportional dwarfs (Conover et al. 2004). The loss of PAPP-A resulted in complete loss of IGFBP-4 proteolytic activity, with no alterations in embryonic IgfII or Igfbp 4 gene expression. The impact of the mutation occurred early in embryo development, prior to organogenesis, affecting skeletal ossification and overall body size. In vitro studies with embryonic fibroblasts derived from these animals supported a role for PAPP-A in regulating IGF-II bioavailability through IGFBP-4 proteolysis (Conover et al. 2004). We reasoned that if the PAPP-A-null phenotype was due to decreased IGF-II bioavailability during embryogenesis, then an increase in IGF-II to an extent that would overcome the inhibitory capacity of IGFBP-4 would rescue the growth retardation resulting from the absence of PAPP-A proteolytic activity.

One way an increase in the amount of IGF-II in mouse embryos could be achieved is through loss of type II 
IGF/mannose-6-phosphate (M6P) receptors. Unlike the type I IGF and insulin signaling receptors, the type II IGF/M6P receptor functions to control extracellular IGF-II concentrations by receptor-mediated endocytosis and subsequent degradation of the growth factor in lysosomes (Braulke 1999). Mice lacking type II IGF/M6P receptors have markedly elevated IGF-II concentrations and exhibit fetal overgrowth due to overstimulation of type I IGF and insulin receptors (Ludwig et al. 1996). However, there are additional severe abnormalities in type II IGF/M6P receptor-null mice, including cardiac defects and edema, and these mice usually die pre- or peri-natally (Lau et al. 1994). Furthermore, the type II IGF/M6P receptor binds other ligands besides IGF-II, such as M6P-containing lysosomal enzymes and retinoic acid, and has additional transport functions (Gosh et al. 2003). To avoid those potentially confounding aspects of the type II IGF/M6P receptor-null mouse model, we chose an alternate approach to increased IGF-II during embryogenesis using $\triangle H 19$ mutant mice.

In mice, the imprinted IgfII gene is located upstream and linked closely to the reciprocally imprinted $H 19$ locus on chromosome 7 (Zemel et al. 1992, Leighton et al. 1995a,b). This linkage between IgII and H19 and their imprinted features are conserved in humans (Zemel et al. 1992). The imprinted $H 19$ gene encodes an untranslated RNA (Brannan et al. 1990, Leighton et al. 1995a,b). According to the Enhancer Competition model, promoters for $\mathrm{H} 19$ and IgfII share enhancers that are expressed downstream of H19 (Bartolomei et al. 1993, Leighton et al. 1995b). Paternal-specific DNA methylation around the H19 gene promoter functions to prevent the interaction of the paternal H19 gene with enhancers, thereby making them available to engage the paternal IgfII gene. On the maternal allele, there is a promoter block in H19 which prevents access to the IgfII promoter by the enhancer elements and, thus, IgfII expression is silenced. Imprinting of the IgfII gene can be disrupted by maternal inheritance of a targeted deletion of the $\mathrm{H} 19$ gene and its $5^{\prime}$ flanking region (Leighton et al. 1995a, Eggenschwiler et al. 1997). Thus, with maternally derived $\Delta H 19$, the normally silent IgfII allele becomes transcriptionally active and the increased amount of IGF-II mRNA from both alleles yields a higher-than-normal level of translation product resulting in increased birth weight (Eggenschwiler et al. 1997). Mice inheriting the H19 mutation from their mothers are 20-30\% larger by weight than wild-type mice or mice inheriting the mutation from their fathers, and they are viable (Leighton et al. 1995a).

Thus, to test the hypothesis that an increase in IGF-II during embryogeneis is sufficient to rescue the dwarf phenotype of PAPP-A mutant mice, we generated $P A P P-A / \Delta H 19$ double mutants and characterized their phenotype in terms of body size and skeletal development in comparison with single mutants and control littermates.
These studies are critical in vivo correlates to in vitro studies defining the regulation and action of PAPP-A.

\section{Materials and Methods}

Mice

The strains of mice used in this study, which carry targeted mutations in the PAPP-A and H19 loci, have been characterized previously (Leighton et al. 1995a, Eggenschwiler et al. 1997, Conover et al. 2004). Details of the genetic crosses to generate double mutants are described in the text. These studies were approved by Mayo's Institutional Animal Care and Use Committee.

\section{Genotyping}

H19 and PAPP-A mutations were detected by Southern analyses as described (Leighton et al. 1995a, Conover et al. 2004). Briefly, for $\Delta H 19$, genomic tail tip DNAs were digested with PstI and hybridized to a ${ }^{32} \mathrm{P}$-labeled probe which detected $6.6 \mathrm{~kb}$ and $3.3 \mathrm{~kb}$ fragments corresponding to the wild-type and mutant alleles respectively. For $P A P P-A$, DNAs were digested with BamHI and hybridized to a ${ }^{32} \mathrm{P}-$ labeled probe that detected $15 \mathrm{~kb}$ and $2.6 \mathrm{~kb}$ fragments corresponding to wild-type and mutant alleles respectively. Since the $15 \mathrm{~kb}$ fragment was not always clearly identified, $P A P P-A$ gene-deletion was confirmed by PCR performed using primers 5'ATG ATT CAT GAG ATT GGG CAT AG $3^{\prime}$ and $5^{\prime}$ TGT TGT AAG GAG TGT TGA AGA AGC $3^{\prime}$ to detect exon 4 in the mouse PAPP-A gene (Conover et al. 2004).

PCR-based sexing of embryos and newborn mice was performed according to the method of McClive and Sinclair (2001), using primer pairs for Sr $\gamma$, the master sex determining gene on the $\mathrm{Y}$ chromosome, and myogenin, a control gene.

\section{Skeletal staining}

Embryos were eviscerated, skinned, fixed in ethanol and then stained with Alcian Blue 8 GS (cartilaginous elements) and Alizarin Red S (mineralized elements), as adapted from McLeod (1980). The tissues were cleared with $1 \% \mathrm{KOH}$, and the skeletons stored in glycerol. Images were captured using a Nikon SMZ800 microscope, DXM1200F digital camera and ACT-1 software (Nikon).

\section{Results}

\section{Genetic crosses}

Mice receiving the $\Delta H 19$ mutation from the maternal allele $(\Delta H 19(\mathrm{~m}-/+))$ have approximately twofold increased levels of IGF-II in the embryo, due to expression 
Table 1 Intercrosses between $\Delta H 19(\mathrm{~m}-/+) / P A P P-A(+/-)$ females and PAPP-A $(-/-)$ males

\begin{tabular}{|c|c|c|c|c|c|c|}
\hline & \multicolumn{2}{|c|}{ Genotype } & \multirow{2}{*}{$\begin{array}{l}\text { Number of } \\
\text { embryos }\end{array}$} & \multirow{2}{*}{$\begin{array}{l}\text { Observed } \\
\text { frequency } \\
(\%)\end{array}$} & \multirow{2}{*}{$\begin{array}{l}\text { Expected } \\
\text { frequency } \\
(\%)\end{array}$} & \multirow[b]{2}{*}{ Male:Female } \\
\hline & $\mathrm{H} 19$ & PAPP-A & & & & \\
\hline \multicolumn{7}{|l|}{ Designation } \\
\hline Control & $+/+$ & $+/-$ & 32 & 24 & 25 & $13: 19$ \\
\hline$\Delta \mathrm{H} 19$ mutant & $m-/+$ & $+/-$ & 31 & 24 & 25 & $14: 17$ \\
\hline PAPP-A-null & $+/+$ & $-1-$ & 37 & 28 & 25 & $19: 18$ \\
\hline Double mutant & $m-/+$ & $-1-$ & 31 & 24 & 25 & $17: 14$ \\
\hline Total & & & 131 & 100 & 100 & $63: 68$ \\
\hline
\end{tabular}

$\mathrm{m}-/+$ : maternal inheritance of mutation.

from both the maternal and paternal alleles, with consequent fetal overgrowth (Leighton et al. 1995a, Eggenschwiler et al. 1997). In contrast, paternal transmission of the mutation $(\triangle H 19(+/ \mathrm{p}-))$ has no phenotypic consequences for the progeny. The PAPP- $A$ gene is not imprinted and both males and females with homozygous deletion are $60-70 \%$ of the body weight of wild-type littermates (Conover et al. 2004). Accordingly, paternally transmitted female $\mathrm{H} 19$ heteroygotes $(\Delta H 19(+/ \mathrm{p}-))$ were first crossed with PAPP-A $(-/-)$ males. Of these offspring, females inheriting the H19 mutant allele $(\triangle H 19(\mathrm{~m}-/+))$ and heterozygous for $P A P P-A$ deletion were again mated to male PAPP-A $(-/-)$ mice (4 breeding cages; 2 females: 1 male) to generate embryos belonging to four genotypic classes (Table 1). Table 1 also shows that the expected Mendelian distribution was observed; therefore, there was no evidence for a genotype effect on viability. Furthermore, there did not appear to be gender bias in the genotypes.

As shown in Fig. 1, deletion of the $H 19$ gene in maternal heterozygotes resulted in a $26 \%$ increase in body mass at birth (1.92 g vs $1.52 \mathrm{~g})$, similar to what has been reported previously (Leighton et al. 1995a, Eggenschwiler et al. 1997). PAPP-A-null mice from these crosses had body weights at birth that were $74 \%$ that of mice heterozygous for the $P A P P-A$ mutation and negative for the $H 19$ mutation $(1.12 \mathrm{~g}$ vs $1.52 \mathrm{~g})$. We used this latter genotype as our control group since, in previous studies, there was no significant difference in body weights between PAPP-A heterozygous and wild-type mice (Conover et al. 2004). Furthermore, additional breeding cages of $4 H 19(\mathrm{~m}-/+) / \mathrm{PAPP}-\mathrm{A}(+/-)$ and PAPP$\mathrm{A}(+/-)$ mice were set up and the newborn weights of PAPP-A $(+/+)$ and PAPP-A $(+/-)$ mice that were $\Delta H 19-$ negative were similar $(1.52 \pm 0.068 \mathrm{~g}$ and 1.55 $\pm 0.027 \mathrm{~g}$ respectively). The reason for differences in absolute birth weights of the PAPP-A $(-/-)$ mice from these crosses and from the previous study (Conover et al. 2004) is unclear, but may be due to the mixed C57Bl/6 backgrounds of the mice in the current study. Importantly, mice that were mutant for both genes were indistinguishable in size from control animals in their birth weights (Fig. 1) and postnatal growth rates (Fig. 2). These phenotype differences were similarly observed if the data were analyzed separately by gender (data not shown).

\section{Skeletal staining}

Embryonic day (E) 16.5 embryos from 4 litters (45 embryos) of $\Delta H 19(\mathrm{~m}-/+)$ mutant and PAPP-A $(+/-)$ crosses were stained for bone and cartilage to determine whether the delay in ossification observed in PAPP-A-null embryos (Conover et al. 2004) could be prevented with increased IGF-II. Genotype and gender were determined for all embryos. Representative embryos are presented in Fig. 3. Overall size differences are evident at E16.5. Thus, $\Delta \mathrm{H} 19$ mutants were larger than controls, and PAPP-Anull embryos were smaller than controls. Double mutants were approximately the same size as the control embryos. In general, skeletal ossification appeared to be similar in

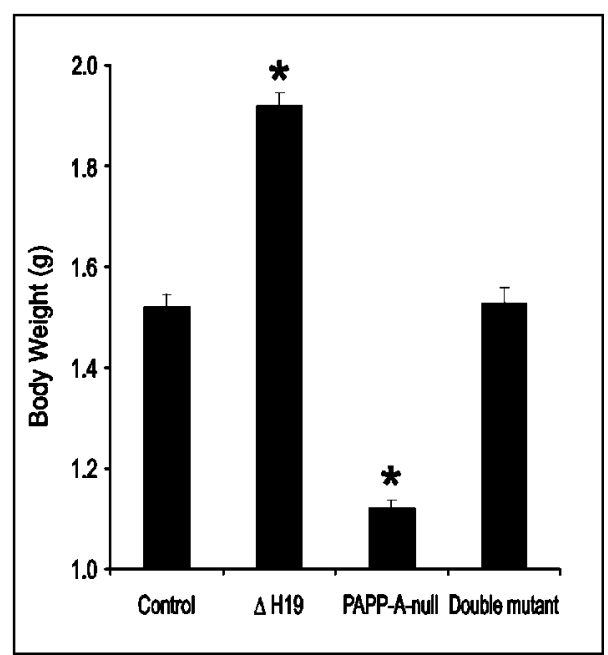

Figure 1 Birth weights of progeny from intercrosses between $\Delta H 19(\mathrm{~m}-/+) /$ PAPP-A $(+/-)$ females and PAPP-A $(-/-)$ males. Results are means \pm S.E.M for the genotypes presented in Table 1. ${ }^{*} P<0 \cdot 001$, significantly different from control. 


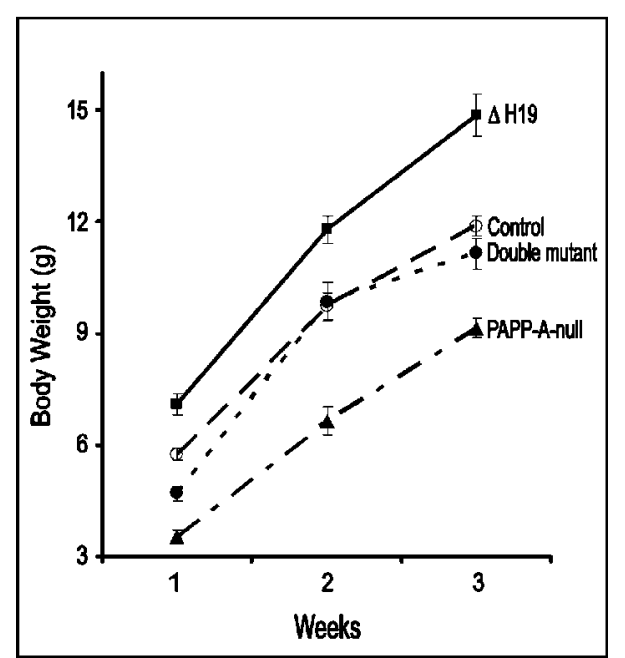

Figure 2 Postnatal growth curves of $\Delta \mathrm{H} 19$ mutant $(\boldsymbol{\square})$, control (O), PAPP-A $(-/-)(\boldsymbol{\Delta})$ and double mutant $(\mathbf{O})$ mice. Values are means \pm S.E.M of 10-30 individual weights.

$\Delta \mathrm{H} 19$ mutants and controls. At this stage of development, there is substantial mineralization of bones that form both via endochondral ossification (vertebrae, peripheral phalanges) and intramembranous ossification (cranial vault) (Ohyama et al. 1997). We generally saw mineralization of 3 to 4 digits, 3 to 4 caudal vertebrae and the frontal, parietal, and interparietal bones of $\Delta \mathrm{H} 19$ mutants and controls. On the other hand, PAPP-A-null mice negative for $\triangle H 19$ mutation showed reduced ossification of the caudal vertebrae, terminal phalanges, and cranial vault (especially the parietal and interparietal bones), as was reported previously (Conover et al. 2004). Embryos with double mutations exhibited skeletal ossification patterns similar to controls.

\section{Discussion}

In this study, we demonstrate that rescue of the growth retardation and delayed ossification that occurs during fetal development in PAPP-A-null mice is associated with increased IGF-II expression during embryogenesis. This was achieved through relaxation of IgfII imprinting via a mutation in the reciprocally imprinted H19. These data support a critical function of the IGFBP protease, PAPP-A, in regulating IGF bioavailability in vivo.

Imprinting signals disrupted by the removal of the H19 promoter from the maternal chromosome leads to the activation of the maternal IgfII gene. This is reflected in approximately twofold increased levels of IGF-II in the embryo due to expression from both the maternal and paternal alleles (Leighton et al. 1995a, Eggenschwiler et al. 1997). Thus, somatic overgrowth of $\Delta H 19$ heterozygotes for the maternal deletion is attributed to the increase in
IGF-II. In this study, inheritance of the $\Delta H 19(\mathrm{~m}-/+)$ mutation and the consequent increase in IGF-II expression rescued the dwarf phenotype of PAPP-A-null mice. This underscores the crucial role of dose regulation of IGF-II, through imprinting and regulated expression of PAPP-A, to the developing embryo. Both growth retardation of PAPP-A-null mice and overgrowth of $4 H 19$ maternal heterozygotes occurred exclusively during embryogenesis, whereas after birth both classes of mutants grew at the same rate as control mice. These findings fit with the model that IGF-II is critical during early embryogenesis for determining optimal body size (Baker et al. 1993, Leighton et al. 1995a, Eggenschwiler et al. 1997, Louvi et al. 1997, Burns \& Hassan 2001). We now add a new dimension to this model by implicating PAPP-A as a key regulator of IGF-II bioavailability during fetal development. Although these, along with our previous in vitro data (Conover et al. 2004), are supportive of the relationship between PAPP-A and IGF-II in fetal development, they do not establish a causal relationship and they do not rule out an effect of PAPP-A on IGF-I bioavailability during later embryogenesis (Baker et al. 1993). Furthermore, these studies do not address the role of IGFBP-4 directly or the possible involvement of other IGFBPs in this model. Refinement of the model will require further study.

The skeletal findings indicate that elevated IGF-II resulting from the $\triangle H 19$ mutation was also associated with rescue of the ossification defects in PAPP-A-null mice. IGF-II has a significant role in embryonic skeletogenesis. In addition to its mitogenic activity, IGF-II promotes differentiation of cells that are primarily of mesodermal origin (Milner \& Hill 1984). IgfII is strongly expressed in head mesoderm, and in the cephalic portion of neural crest cells, somites forming the axial skeleton, and lateral mesoderm forming limb buds (Stylianopoulou et al. 1988, Lee et al. 1990). The pattern of IgfI gene expression during embryogenesis overlaps significantly with $P A P P-A$, which is also expressed in head mesenchyme and neural crest cells, somites and limbs (Stylianopoulou et al. 1988, Lee et al. 1990, Conover et al. 2004). Importantly, there is a striking association of IgfII and Igfbp 4 gene expression (Cerro et al. 1993, Schuller et al. 1993), thereby allowing establishment of an IGF-II/IGFBP-4 reservoir that could be rapidly accessed by regulated increases in PAPP-A expression. Besides the proposed roles in embryological development, the PAPP-A/IGFBP-4/IGF system may be involved in post-natal bone formation as well, since PAPP-A and IGFBP-4 are highly expressed by osteoblasts and have been shown to regulate IGF action in these cells in vitro (Wang et al. 1995, van Kleffens et al. 1998, Ortiz et al. 2003). Furthermore, the importance of regulation of local IGF action in adult bone by PAPP-A is suggested by the finding of defective fracture repair in PAPP-A-null mice (Miller et al. 2004).

In conclusion, these data provide strong genetic evidence that PAPP-A plays a unique role pre-natally that 


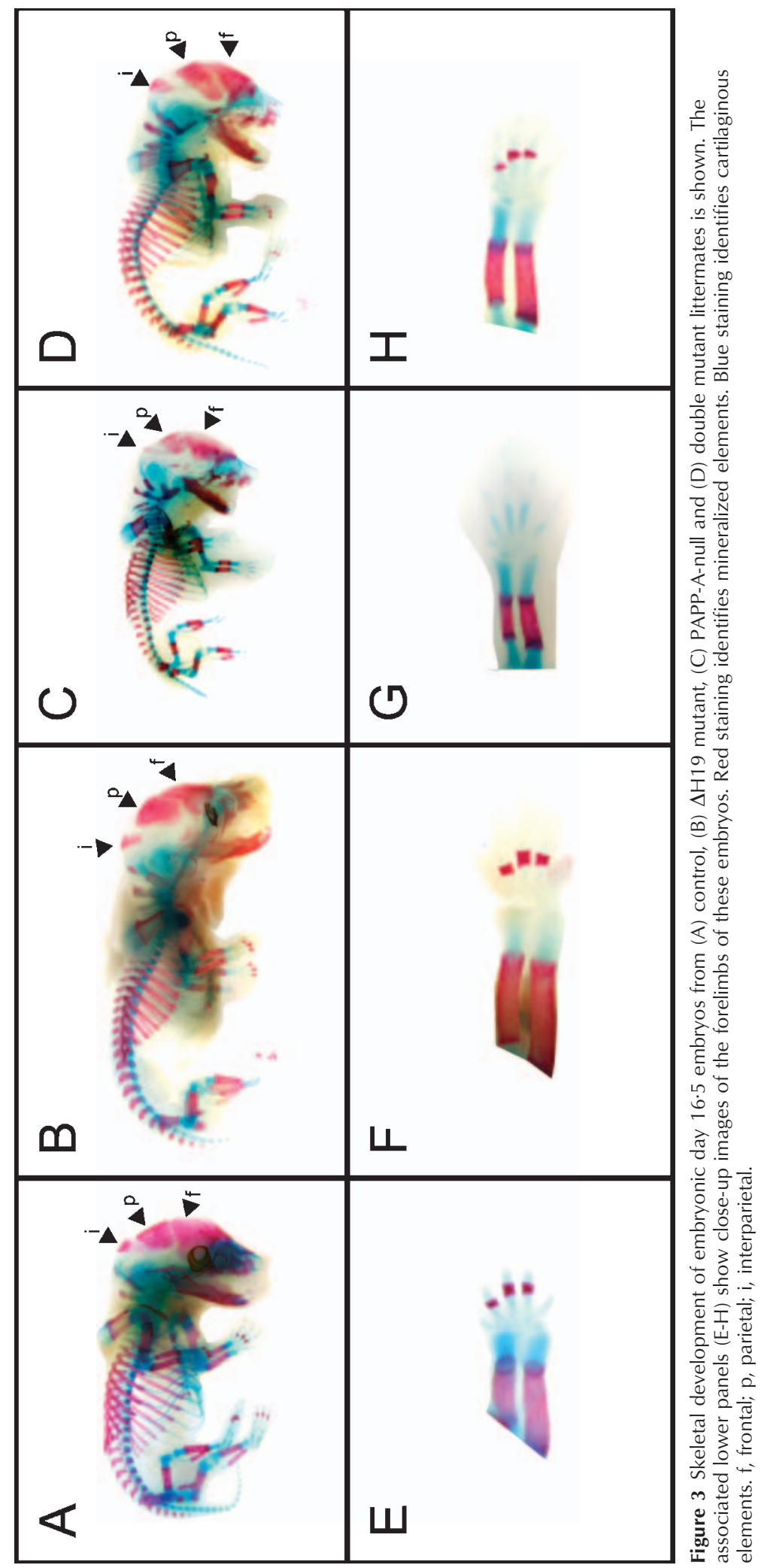


involves the optimization of specific IGF-II action. This is a new concept critical to our understanding of the IGF system in vivo. Furthermore, these findings implicate a similar role post-natally in IGF-mediated wound healing, bone remodeling, and vascular repair (Bayes-Genis et al. 2001, Chen et al. 2003, Miller et al. 2004), and perhaps other as yet undetermined events in which locally regulated IGF bioavailability has physiologic and pathophysiologic importance.

\section{Acknowledgements}

The authors thank Dr Efstratiadis for helpful discussion, Dr Tilghman for permission to use the $\Delta H 19$ mutant mice, Dr Kalli for critical reading of the manuscript, and Paul J Hubbard, Tara L Potts, and Sean C Harrington for excellent technical assistance.

\section{Funding}

This work was supported by the Mayo Foundation. The authors declare that there is no conflict of interest that would prejudice the impartiality of this scientific research.

\section{References}

Baker J, Liu J-P, Robertson EJ \& Efstratiadis A 1993 Role of insulin-like growth factors in embryonic and postnatal growth. Cell 75 73-82.

Bartolomei MS, Webber AL, Brunkow ME \& Tilghman SM 1993 Epigenetic mechanisms underlying the imprinting of the mouse H19 gene. Genes and Development 7 1663-1673.

Bayes-Genis A, Schwartz RS, Lewis DA, Overgaard MT, Christiansen M, Oxvig C, Ashai K, Holmes DR Jr \& Conover CA 2001 Insulin-like growth factor binding protein-4 protease produced by smooth muscle cells increases in the coronary artery after angioplasty. Arteriosclerosis, Thrombosis and Vascular Biology 21 335-341.

Brannan CI, Dees EC, Ingram RS \& Tilghman SM 1990 The product of H19 gene may function as an RNA. Molecular and Cellular Biology 10 28-36.

Braulke T 1999 Type-2 IGF receptor: a multi-ligand binding protein. Hormone and Metabolic Research 31 242-246.

Bunn RC \& Fowlkes JL 2003 Insulin-like growth factor binding protein proteolysis. Trends in Endocrinology and Metabolism 14 176-181.

Burns JL \& Hassan AB 2001 Cell survival and proliferation are modified by insulin-like growth factor II between days 9 and 10 of mouse gestation. Development 128 3819-3830.

Byun D, Mohan S, Yoo M, Sexton C, Baylink DJ \& Qin X 2001 Pregnancy-associated plasma protein-A accounts for the insulin-like growth factor (IGF)-binding protein-4 (IGFBP-4) proteolytic activity in human pregnancy serum and enhances the mitogenic activity of IGF by degrading IGFBP-4 in vitro. Journal of Clinical Endocrinology and Metabolism 86 847-854.

Cerro JA, Grewal A, Wood TL \& Pintar JE 1993 Tissue-specific expression of the insulin-like growth factor binding protein (IGFBP) mRNAs in mouse and rat development. Regulatory Peptides 48 189-198.
Chen B-K, Leiferman KM, Pittelkow MR, Overgaard MT, Oxvig C \& Conover CA 2003 Localization and regulation of pregnancy-associated plasma protein-A expression in healing human skin. Journal of Clinical Endocrinology and Metabolism 88 4465-4471.

Conover CA, Durham SK, Zapf J, Masiarz FR \& Kiefer MC 1995 Cleavage analysis of insulin-like growth factor (IGF)-dependent IGF-binding protein-4 proteolysis and expression of protease-resistant IGF-binding protein-4 mutants. Journal of Biological Chemistry 270 4395-4400.

Conover CA, Bale LK, Overgaard MT, Johnstone EW, Laursen UH, Füchtbauer E-M, Oxvig C \& van Deursen J 2004

Metalloproteinase pregnancy-associated plasma protein A is a critical growth regulatory factor during fetal development. Development 131 1187-1194.

DeChiara TM, Efstratiadis A \& Robertson EJ 1990 A growth-deficiency phenotype in heterozygous mice carrying an insulin-like growth factor II gene disrupted by targeting. Nature 345 $78-80$.

Eggenschwiler J, Ludwig T, Fisher P, Leighton PA, Tilghman SM \& Efstratiadis A 1997 Mouse mutant embryos overexpressing IGF-II exhibit phenotypic features of the Beckwith-Wiedemann and Simpson-Golabi-Behmel syndromes. Genes and Development $\mathbf{1 1}$ 3128-3142.

Gosh P, Dahms NM \& Kornfeld S 2003 Mannose 6-phosphate receptors: new twists in the tale. Nature 4 202-212.

van Kleffens M, Groffen C, Rosato RR, van den Eijnde SM, van Neck JW, Lindenbergh-Kortleve DJ, Zwarthoff EC \& Drop SLS 1998 mRNA expression patterns of the IGF system during mouse limb bud development, determined by whole mount in situ hybridization. Molecular and Cellular Endocrinology 138 151-161.

Lau MMH, Stewart CEH, Liu Z, Bhatt H, Rotwein P \& Stewart CL 1994 Loss of the imprinted IGF-II/cation-independent mannose 6-phosphate receptor results in fetal overgroth and perinatal lethality. Genes and Development 8 2953-2963.

Lawrence JB, Oxvig C, Overgaard MT, Sottrup-Jensen L, Gleich GJ, Hays LG, Yates JR III \& Conover CA 1999 The insulin-like growth factor (IGF)-dependent IGF binding protein-4 protease secreted by human fibroblasts is pregnancy-associated plasma protein-A. PNAS 96 3149-3153.

Lee JE, Pintar J \& Efstratidais A 1990 Pattern of the insulin-like growth factor II gene expression during early mouse embryogenesis. Development 110 151-163.

Leighton PA, Ingram RS, Eggenschwiler J, Efstratiadis A \& Tilghman SM 1995a Disruption of imprinting caused by deletion of the H19 gene region in mice. Nature 375 34-39.

Leighton PA, Saam JR, Ingram RS, Stewart CL \& Tilghman SM 1995b An enhancer deletion affects both H19 and Igf2 expression. Genes and Development 9 2079-2980.

Louvi A, Accili D \& Efstratiadis A 1997 Growth-promoting interaction of IGF-II with the insulin receptor during mouse embryonic development. Developmental Biology 189 33-48.

Ludwig T, Eggenschwiler J, Fisher P, D'Ercole AJ, Davenport ML \& Efstratiadis A 1996 Mouse mutants lacking the type 2 IGF receptor (IGF2R) are rescued from perinatal lethality in Igf2 and Igf1r null backgrounds. Developmental Biology 177 517-535.

McClive PJ \& Sinclair AH 2001 Mouse mutant embryos overexpressing IGF-II exhibit phenotypic features of the Beckwith-Wiedemann and Simpson-Golabi-Behmel syndromes. Molecular Reproduction and Development 60 225-226.

McLeod MJ 1980 Differential staining of cartilage and bone in whole mouse fetuses by Alcian Blue and Alizarin Red S. Teratology 22 299-301.

Miller BS, Bronk JT, Nishiyama T, Yamagiwa H, Srivastava A, Bolander ME \& Conover CA 2004 Absence of PAPP-A causes delayed fracture healing in mice. Proceedings of the 86th Endocrine Society Meeting, June 16-19 2004, p 492. New Orleans, LA (Abstract). 
Milner RDG \& Hill DJ 1984 Fetal growth control: the role of insulin and related peptides. Clinical Endocrinology 21 415-433.

Ohyama K, Chung C-H, Chen E, Gibson CW, Misof K, Fratzl P \& Shapiro IM 1997 p53 influences mice skeletal development. Journal of Craniofacial Genetics and Developmental Biology 17 161-171.

Ortiz C, Chen B-K, Bale L, Overgaard M, Oxvig C \& Conover CA 2003 Transforming growth factor- $\beta$ regulation of the insulin-like growth factor binding protein-4 protease system in cultured human osteoblasts. Journal of Bone and Mineral Research 18 1066-1072.

Pintar J, Schuller A, Bradshaw S, Cerro J \& Grewal A 1998 Genetic disruption of IGF binding proteins. In Molecular Mechanisms to Regulate the Activities of Insulin-Like Growth Factors, pp 65-70. Eds K Takano, N Hizuka \& S-I Takahashi. Amsterdam, Holland: Elsevier Science.

Rechler MM \& Clemmons DR 1998 Regulatory actions of insulin-like growth factor-binding proteins. Trends in Endocrinology and Metabolism 9 176-183.

Schuller AGP, van Neck JW, Lindenbergh-Kortleve DJ, Groffen C, de Jong I, Swarthoff EC \& Drop SL 1993 Gene expression of the IGF bindig proteins during post-implantation embryogenesis of the mouse: comparison with the expression of IGF-I and -II and their receptors in rodent and human. Advances in Experimental Medicine and Biology 343 267-277.

Shimasaki S \& Ling N 1991 Identification and molecular characterization of insulin-like growth factor binding proteins (IGFBP-1, -2, -3, -4, -5 and -6). Progress in Growth Factor Research $3243-266$.

Stylianopoulou F, Efstratiadis A, Herbert J \& Pintar J 1988 Pattern of the insulin-like growth factor II gene expression during rat embryogenesis. Development 103 497-506.

Wang E, Wang J, Chin E, Zhou J \& Bondy CA 1995 Cellular patterns of insulin-like growth factor system gene expression in murine chondrogenesis and osteogenesis. Endocrinology 136 2741-2751.

Zemel S, Bartolomei MS \& Tilghman SM 1992 Physical linkage of two mammalian imprinted genes, H19 and insulin-like growth factor 2. Nature Genetics 2 61-65.

Received 28 March 2005

Accepted 8 May 2005 